\title{
What are ABER and CAP?
}

\section{Peter Gouzouasis, Guest Editor}

The introduction to this special issue is written in a storied manner to ready the reader for the unique, storied forms of research that follow. I wholeheartedly suggest that readers not read the abstracts of the each paper first, but delve directly into the stories and engage with the music and media. These papers are not intended as a definitive collection of arts based educational research and creative analytical practices in music and music education. Rather, this special issue is a beginning-an opening - that represents where we are in 2019, as a profession, in our understandings and applications of contemporary forms of qualitative research.

Keywords: arts based educational research (ABER), creative analytical practices (CAP), autoethnography, creative non-fiction, life stories, music, a/r/tography

This turn toward practical philosophy takes up several ideas. It means (a) that conceptions of the aim of social inquiry are now being shaped not by the demand for a "neutral, objectifying science of human life and action" (Taylor 1987, 472) or for episteme but by the search for a better understanding of praxis; (b) that the kind of investigation required here must attend to both ethical and political concerns (ethical because praxis [action] is defined by habits, modes of thought, customs, and mores and political because action is public and is concerned with our lives in the polis; Bernstein 1991)... (Schwandt 1996, 62)

$\mathrm{I}$ n 1978, William Pinar began his landmark paper "What is the Reconceptualization?" in the first issue of the Journal of Curriculum Theory with the comment, "I'm not going to answer that question." Like my colleague, who has an office down the hall from mine, I'm not going to answer the question posed in the title of this introduction. But I can guide readers to literature that can help them develop understandings and facilitate their own journeys into these forms of inquiry.

The three years prior to the turn of the new millennium, Barone and Eisner (1997) wrote a landmark paper in which they theorized and demonstrated a new way of thinking about using artistically shaped lenses in empirical forms of

(C) Peter Gouzouasis. 2019. The content of this article is the sole responsibility of the author. The ACT Journal and the Mayday Group are not liable for any legal actions that may arise involving the article's content, including, but not limited to, copyright infringement. 
research. The movement toward new research forms had been brewing, some could say, since Eisner's earlier writings (1971) about assessment and the arts and Pinar's (1975) conception of curriculum as an autobiographical process. A number of MA theses and PhD dissertations were born at The University of British Columbia (see Sinner, Leggo, Irwin, Gouzouasis, and Grauer 2006) between 1994 and 2004-over 30 dissertations that influenced a new, broader approach to arts research and artistic forms of inquiry-and a handful of those works shaped the ways that I would work with graduate students over the next two decades (e.g. see Beer 1999; Darts 2004; de Cosson 2003; Fels 1999; Kirkland 2004; Lee 2004; Miller 2002; Rasberry 1997; Thompson 2001).

When I was initially invited to guest edit the present special issue, I never intended an introduction to be a history of Arts Based Educational Research (ABER) and Creative Analytical Practices (CAP). While I have favorite papers and books, and guide students in graduate classes to read certain works by key authors, I neither search for nor expect to find definitive examples of these research forms. As there is not one way to learn to play guitar, there is no single book, approach, or 'method' for learning how to work in (and through) arts research forms and apply them-sensibly, sensitively, and effectively-to a variety of research questions that cannot be answered through applications of other, more traditional research approaches. In fact, most handbooks and textbooks written for ABER and CAP fall short in providing a broad overview of what is now a very mature, rich historical landscape of research. While some try to generalize about various categories of ABER and CAP, I consider the majority of papers of these genres over the last 10 years to be unique and distinctive. Most important, the distinctions between various forms of ABER and CAP seem 'blurred' as writers across many disciplines employ a fusion of approaches in composing papers.

Like Van Maanen, who considered reading as a creative act $(1988 ; 1995,26)$, Dunlop (2006) invites us to consider "reading as an imaginative act." Obviously, writing, reading (i.e. through audiation), and making music are also imaginative acts, as writing and writing about making music can be imaginative and creative. From 1997 to 2004 I delved into every issue of journals that had nothing to do with music and music education. ${ }^{1}$ Through that process I came to realize how the landscape of writing in our profession had become mired in positivist and post-positivist research paradigms (Denzin and Lincoln 2000). In the 1980s, we were taught that philosophical and historical work comprised qualitative research in music 
education. ${ }^{2}$ For that reason, and relating that orientation to my own journey as a scholar as one example, the observational notes I had meticulously taken during weekly 'data collection' in pre-school music classes were removed from the 'results' chapter of my M.A. thesis because "it didn't belong in a quasi-experimental study." 3 As I'd adopted an organicist stance through two graduate courses with developmental psychologist Willis Overton (1983-1984),4 I struggled (1) with reading and trying to apply 'practical significance' from the hundreds of one shot, small scale quasi-experimental studies in our profession that claimed 'statistical significance' in their findings, (2) with the knowledge that an organismic stance invited both qualitative and quantitative research because the purpose and problems guide the researcher to choose the appropriate method to answer the questions in the line of an inquiry, and (3) in coming to terms with the realization that everything I'd been taught to believe about research in music learning and teaching through quasi-experimental, historical and philosophical lenses was antiquated, narrow, and outdated. To change, I needed to adopt a perspective of "qualitative research as a form of radical democratic practice" (Denzin and Lincoln 2008, viii) and read hundreds of papers outside of our profession because there was no literature base in music and music education.

Every time I teach autoethnography I use a handful of core readings that I consider somewhat 'foundational' to understanding ABER and CAP, as well as lead learners to see the similarities and differences between various forms of inquiry. I also encourage learners to not only read those papers, but to delve into the references-and the references of the references-to develop a deep understanding of a particular technique or literary device and in a broader sense, experience firsthand the evolution of ABER and CAP. I do not believe I can convince all readers of this special issue of the verisimilitude, tensility, impact (Gouzouasis 2008), meanings (Eisner 1995), truth (Phillips 1995), interpretation, or generalizability of these genres of research writing that emerged in the last two decades of the 2oth century and have flourished in many research fields-from nursing to sports, exercise and health, to sociology, to communications, to education-in this new millennium. My hope is that the present collection of works leads us to question, not whether there is a future for ABER and CAP in our profession, but rather to ponder how, when, where, and why ABER and CAP forms may continue to emerge and develop as engaging, accessible forms of music research that can be read and discussed beyond circles of academic discourse. Thus, in a sense, this introduction may provide an 
entrance to a trace5 that can lead a person to begin an exploration of these approaches.

In 1999, Bruce Kilbourn's concern was with fictional forms of writing in research, but a few years earlier, Eisner (1995) had already emphasized multiple forms of representation of empirical evidence (i.e. personal experiences, observed, experiences) and encouraged arts researchers to adopt more inviting and accessible research styles and conventions. Numerous papers and book chapters written in the 1990 and early 2000 s provide detailed discussions of how literature, methodologies, design considerations, results, and 'conclusions' can be transformed through contemporary qualitative writing in educational research. Typically, these forms of inquiry take the most engaged student of ABER and CAP four to six years to synthesize and apply in a dissertation, and in that time frame they are still unable to explore the entire base of literature. That point has been disconcerting to me for the past 5 years. The literature base is so broad, these research approaches have permeated so many topics, and there is no pseudo-scientific formula to 'do' arts based research. Yet one insight is very clear-the music education profession is at least 20 years overdue in publishing a special issue on ABER and CAP.

Social inquiry ought to generate knowledge that complements or supplements rather than displaces lay probing of social problems. (Schwandt 1996, 69)

Janesick (2001) writes, "the story is paramount. And nothing is so important to the story as the words we use, both intuitively and creatively" (539). Stories, narratives, tales-these terms have been used in a variety of nuanced ways since Bruner's (1991) theoretical discussion of how story enables us to construct reality. In the fields of sociology and communications, Ellis, Adams, and Bochner (2011) conceptualize autoethnography as "an approach to research and writing that seeks to describe and systematically analyze personal experience in order to understand cultural experience" (273). Autoethnography was born out of ethnography, the study of culture (ethos) through the process of writing (graphy). A common, early characteristic of that form of research was the sharing of epiphanies (Bochner and Ellis 1992; Pelias 2000; Banks and Banks 2000; Couser 1997; Gouzouasis and Lee 2002; Sparkes 2002). Traditionally speaking, autoethnography focuses on the researcher as 'self'6 (Ellis 2004). Many researchers (Eisner and Barone 1997; Ellis 2004; Irwin and de Cosson 2002) note how placing one's self within the research can be mutually beneficial to the author and reader alike (i.e. 'self' and 'other'). Furthermore, Gouzouasis and Lee (2016) state the goal of writing stories in artistic, 
creative non-fictional forms, autoethnographically, "is to convey meanings and not merely portray facts" (346). But it is also to reach a wider audience, to make our understandings and findings of studies more accessible, and subsequently, more meaningful for the reader. When we interpretively apply and consider the notion of 'auto' in multiple contexts, the term 'auto' reveals details not only of the 'self,' but rich, fecund notions of him, her, other, this, that, those, and them in various day-to-day culturally placed experiences (see Gouzouasis and Ryu 2015; Gouzouasis and Leggo 2017; Gouzouasis 2018). While my expanded interpretation and choice of words may be novel, these ideas are not new by any means.

I present myself not so much to tell stories, but rather to participate in a questioning of the questions we typically ask when we, in and through our very living, tell our stories-stories that inevitably tell who we are and, as well, our understanding of how our world is. (Aoki 1987/2005, 349).

In Kilbourn's previously mentioned essay (1999), he cites a body of work by Stephen Pepper on structural and multiplicative corroboration to discuss the nature of 'data' (i.e. which he refers to as "evidence") to develop a rationale for the reader to accept, or reject, fictionally styled writing as research. I have drawn from Pepper's work over the years to build an argument, through a storied dialogue with graduate students not unlike Wiley's in the present collection, for using new terminology to describe the plausibility and soundness of arts based research work (see Gouzouasis 2008). However, Kilbourne neither cited nor discussed the groundbreaking dissertation by Rishma Dunlop, Boundary Bay. 7

Personal life histories are considered self-life-writings, or autobiographies. Over the past 3 decades that span my academic career, educational researchers have explored the 'self' by writing lived experiences in a lively, engaging, sensuous, visceral, creative, imaginative, storied manner that not only includes the writer's voice (Leggo 1995) but multiple voices of characters who share those experiences (e.g. Richardson 1998; Dunbar 1999; Ellis 2004; Gouzouasis 2008). Life's characters-students, teachers, colleagues, parents, friends, acquaintances-intersect and interact with a writer in the day to day of life's experiences to create a storied, imaginary vivacity.

Arguably, the significance of the arts lies in their fundamentally ontological character ... their ability to raise issues of existence and being to the level of consciousness. (Pike 2004, 24) 
The collection of works in the present, special issue neither features definitive examples nor 'absolute exemplars' of ABER and CAP. They represent where we are today, as a profession, in our understandings and applications of contemporary forms of qualitative research. As such, they may be open to critique; however, critique needs to be made on foundational issues that have been discussed and addressed in and around these genres since their inception; that also follows for the terminologies and understandings the authors have applied. In consideration, we were very fortunate to receive the interest we generated from the call for papers. That we have an international collection of works is noteworthy-papers are from Australia, Canada (by way of Ireland), England, Finland (by way of Spain), Greece, New Zealand, Scotland, and the USA (New Jersey). That we have the highest quality of music interwoven with the stories is also very important and in that way, for the broader academic community these papers will serve as exemplars for what inquiry should read and sound like when musicians engage with ABER and CAP. These are not 'anything goes,' 'hippy dippy' stories of music learning and teaching. Taken individually and collectively, these works open a needed and necessary 'toolbox' through which we can begin to study research questions that have either been written about using positivist and post-positivist methods in music education or not been explored because we lacked the techniques and methodological foundation to do so. On those points alone, I am confident that these works should resonate with readers across music education and other academic communities.

Due to advances in digital technologies, what is possible in 2019 and admissible as a 'text' in an academic journal is far different from 20 years ago. In the present special issue, you will hear music composed and performed by 'real' musicians, and to that I say, "Well done."

The outcome of social inquiry as practical philosophy can be judged in terms of whether the social inquirer or inquiry team is successful at enhancing or cultivating critical intelligence in parties to the research encounter (Schwandt 1996, 69)

\section{The essays of the special issue}

On my first visit to Corfu town in May 2014, where I'd been whisked from Thessaloniki by Dr. Zoè Dyoníssiou (Ionian University) the day after a workshop and lecture with the Greek Society of Music Education, I was invited to sit in on a class guitar session that was held on the back mezzanine of a quaint, but somewhat 
funky, book shop. I was told nothing about the group, the music, the teaching, and the learning approach. After the first song, I was easily convinced of the efficacy the approach-the informality of the experience, the collegiality, the diversity of the group, the teaching and learning process, the level of engagement, the musicality of the group, the seriousness and sense of humor of group members. My immediate impression was that this was a necessary research project-one that could encompass community music and socioemotional learning. Still, I wondered how my colleagues would write about such a complex, subjective learning experience. Earlier that day, I'd shared a research presentation on what was a forthcoming paper (Gouzouasis and Ryu 2015) and I was certain that my observations and handson experience of the guitar group could be best written as an ABER paper. What I first found most fascinating and noticeable was the use of $\mathrm{G}$ minor open tuning, mainly because all the open tunings I'd ever used in performing and teaching were either major in orientation or amorphously modal (e.g. DADGAD; open D, DADF\#AD; open G, DGDGBD). Any doubts I had about the efficacy of such an approach were mitigated when I audiated my past music experiences and quickly realized that Greek popular music uses minor tonality and many minor chord progressions.

Of course, I'd traveled with my Larrivée parlor guitar, so I tuned out of standard tuning and participated in the music making. Entrainment is the word that most accurately represents the feelings I experienced through synchronous guitar playing, emotional singing, and recollections of my father singing many of the songs in the repertoire. I always become very emotional when I hear those songs because I can still hear his voice and visualize his elegant solo dancing. ${ }^{8}$ One of the guitar learners with whom I shared the same first name ('Pantelìs') gifted me with two, frozen, plastic water bottles filled with homemade 'tsipouro.' I interpreted that as evidence of my 'fitting in' with the group, not merely as an academic, 'objective' observer but as a participating member who shared the 'communion' of a heartful music making experience.

For three years, Dr. Ioanna Etmektsoglou and I continued a conversation around her guitar project, and what emerged from our correspondence is what we are blessed to have in the special issue. I characterize the writing as the traditional narrative inquiry style of writing, leaning somewhat more toward the more 'impressionist' works of people like Carl Leggo and Rishma Dunlop rather than more conservative, 'Baroque' styled compositions of Jean Clandinin, Frank Connolly, 
Mary Beattie, Cheryl Craig, and others who developed the form in the 1990s. ${ }^{9}$ That said, all of those authors play an important role in understanding the lineage and development of ABER (and CAP). While not a full-length documentary in the commercial sense of the term, the film documents the 'actual' thoughts, images and feelings of Guitar Express participants. On a subsequent visit to Corfu in April 2018, the premier screening of the film inspired me to entreat Dr. Etmektsoglou and Ms. Kerzeli to write the paper and share the film in the present issue.

I have been perplexed with the notion of 'pedagogy' applied to adult learning for the past 35 years. Since engaging with 'learning stories' (Carr 2001; Carr and Lee 2012; Gouzouasis and Yanko 2018a, 2018b) with a graduate student-expert teacher some 6 years ago, and being very familiar with Banks and Banks (2000) notion of autoethnography as a pedagogical process, I came to the realization that becoming a reflexive practitioner through that inquiry process is an example of autoethnography as an 'enilikological' experience (Yanko and Gouzouasis, in press). ${ }^{10}$

Louise Godwin's work is important as a 'model' for the many editors with whom I've worked over the past 20 years, particularly from 2000-2015. Non-musicians seem to have no clue as to why it is important to include links to music and music notation in scholarly writing. While I've always realized that most readers of educational research are musically illiterate, just as music educators believe that children should see and engage with music notation (i.e. invented and traditional) to develop an understanding of the art form, it's equally important for non-musician adults to see and at least engage with music notation. Within this essay, and others in the present collection, musicians' voices are 'heard' not only in silent audiation of notation, but also in robust, fully sounding voices.

Not knowing what other authors in this collection have written, notions of being and becoming (see Gouzouasis, Irwin, Gordon and Miles 2013) are also a prevalent theme of Godwin's autoethnographic conversation. The skillful manner in which she weaves back and forth, in and out, through past-present-future, with musical and textual ideas, may be a challenge for some readers unfamiliar with the confessional tale genre that was prevalent in dozens of early autoethnographic works of the 1990s. And the even earlier work of the 'other' Van Maanen, John (1988), who introduced us to the notion that research stories may be considered as 'tales of the field.' That said, Godwin has skillfully written a heartfelt, revealing essay that will provide a model for others to reference into the next decade. 
Christopher Wiley's use of "So What?" was a wonderful coincidence because the first, large scale, performative piece of ABER ever presented at a music education conference was with my five $\mathrm{PhD}$ students at the Narrative Inquiry in Music Education (NIME) conference (2005) at Arizona State University where we shared stories, poetry, and many forms of music that were interwoven into rondo form. The Miles Davis piece "So What?" was the theme of our repeating A section. However, we improvised on the chord progression and never revealed the 'head' so only one person in the audience knew and understood what we kept provoking over the course of the 70-minute performance. ${ }^{11}$ That really surprised us (i.e. not knowing the recurring theme, but not the sleeper). As Wiley notes in his essay, I had numerous problems with an editor who refused an unusual representation of a fugal form in a paper I co-authored with Karen V. Lee (2002), so this is my opportunity to encourage other writers to explore new representations of form in writing when metaphorically connecting text with music form. I find that the use of arts based forms of performative writing useful and effective ways to discuss methodological, ontological, and epistemological concepts; if written in strict, academic essay format those topics typically disengage many graduate student readers after reading the opening pages. When a colleague questioned our use of a multi-voiced story to discuss research methods (see Gouzouasis, Bakan, Ryu, Ballam, Murphy, Ihnatovych, Virag, and Yanko 2014) at a MayDay Colloquium hosted at the University of British Columbia (2013) - I suggested that 'even' Plato used traditional and invented myths ${ }^{12}$ that feature the voices of multiple characters in conversation. For the ancient Greeks, Plato wrote 'true' stories as discourse to reach a wide audience of readers, because it was a philosopher's job not only to 'think' and write deep ideas but also share them with those who do not dedicate their lives to such pithy endeavors. Laurel Richardson (1990, 2000, 2013) revived that particular notion of how the 'audience matters' in sociology.

The use of music to evoke thoughts and memories is prevalent in the multimedia exposè (and the text based, essay transcript of this collection) by Colleen Sears. When I first sent Sears' work for reviews, it was in a 'not too friendly' multimedia format, but the essence of the thoughts, feelings, sounds (music) and images were so powerful that I felt it necessary to work with the author to sculpt this work into its present form. Also, we are fortunate for her efforts in providing a transcription, in text format. The notion of 'epiphony' (Gouzouasis 2013, 14; Deo and Gouzouasis 2018) is featured in other essays in the current collection (e.g. López-Íñiguez) and 
is prominent here. For many musician authors of autoethnography it becomes a recurrent theme in their lives and the experiences of other musicians. Hearing a piece of music from one's past can trigger not only sudden memories of when one experienced that music for the first time, but also ideas and realizations of events connected to music. ${ }^{13}$

Sears's use of the quote, "Good teachers possess a capacity for connectedness. They are able to weave a complex web of connections among themselves, their subjects, and their students so that students can learn to weave a world for themselves. The connections made by good teachers are held not in their methods but in their hearts" (Palmer 2007), evokes a reminder that relates to the function of autoethnography as more than merely relating experiences to, and of, the self (the 'auto', pronounced 'afto' in Greek)-that 'auto' has multiple, contextualized, potential meanings and uses-self, him, her, this, that, those, them, other ${ }^{14}-$ weaving reflexive possibilities that autoethnography potentially realizes far beyond self-reflective inquiry prevalent in teacher research (see Schön 1987). As Vikki Hillis (Huebner 1999) writes, "There is healing work to be done, as there always has been and will be" (xiv). Those words ring truthfully, not only for Sears, but all the authors in this special issue.

When I heard Te Oti Rakena sing a Mōteatea (a type of Māori song) and present his spirited 'non keynote' address at the 2017 World Alliance of Arts Education, my first thought was "this is performative writing as arts based research" at its finest. That conference participants were invited into such a meeting place, "an ancestor-god that all the children of the South Pacific can identify with," was striking. Even more surprising was that we were invited to participate in a Māori ritual. It rarely happens that non-natives of other cultures are honored to partake in such a powerful, soulful ceremony. ${ }^{15}$ Moreover, I was surprised as we entered the space that non-Māori New Zealanders were part of a chorus that sang to us in the Eastern Polynesian language spoken by Māori people. Another surprise was the operatic voice that Te Oti used to sing for us, and his description of the tensions between being a person of non-Western descent singing in a style developed by 'colonial' cultures is an interesting journey of reconciliation between university lecturer and indigenous community member all the more meaningful. But Rakena's inquiry offers much more than the reconciliation of how we participate in and use indigenous and Western music. It offers the hope of using all that makes us human in the 21st century to learn and live through the arts-in particular, community music-to 
create new knowledge and offer a hope of deep, radical transformation of systems of negative, oppressive power structures. For me, Rakena's essay is a living example of how we can all come to understand our place in the world through both intraand inter-personal reconciliation.

Similar to my experience of seeing and hearing a proto version of Te Oti Rakena's paper, I heard Lucy Hollingsworth present a paper at a conference on music and autoethnography in London, England (April 2018). An accomplished composer and doctoral candidate, her work reminded me of the many times I've been a university examiner on doctoral defenses at UBC, imagining that if only the people in the School of Music were familiar with contemporary research in the social sciences nearly all of the composition and performance D.M.A. degrees I've attended could be transformed into Ph.D. degrees. Drawing parallels with the negativity of an unsupportive spouse and the life of Ruth Crawford Seeger, she captures what many women have experienced, ${ }^{16}$ married to unsupportive, abusive spouses. The transformative nature of music-particularly through the processes of composition and performance-and the personal travails of a musician-researcherteacher has not been widely written about as a research topic in our profession (Bakan 2014). From this effort, and the splendid music that was inspired by the image of an owl in a snowstorm, we learn that music can function as creative autoethnography in and of itself.

Recently, I listened to a recent recording of Guadalupe López-Íñiguez playing the Largo from the Sonata in A by Domenico Gabrielli. I first read some of her papers five years ago, on a social networking site for academics. While they were well written, and impressively featured in traditional psychology journals, I could only consider how the topics could be explored in an autoethnographic form. López-Íñiguez and I began a respectful dialog, and over the years she read many of my works and those of select papers I suggested from my various course syllabi. Now, we have the opportunity to read a beautiful fusion of an autoethnographically written narrative ${ }^{17}$ and brilliantly performed music by a professional cellist (artist)/researcher/teacher, an a/r/tographer in the core sense of the term. That she focused on a key concept of autoethnography, the epiphany/epiphony, ${ }^{18}$ was not surprising to me when I received the first draft of her inquiry. For anyone who has spent their life in music and education, music is always an evocation-of past experiences with people, places, things, teaching, and learning. This is not unlike what Colleen Sears discovered through her reflexive essay. Having experienced 
taunts, bullying, musical performance experiences, and pitfalls as Guadalupe has in her lifetime, her descriptions deeply resonate with me. Culture is an essential facet of the 'ethno' of autoethnography. López-Íñiguez's culture, growing up in Spain and coming from a family that could not afford lessons and musical instruments, is not only her theme, rather it is one for many of us who engage with and teach music.

As one example of relationality when storying the 'auto,' in the mid 1930s, my grandfather paid a guitarist in Pireaus, Greece to teach my father to play guitar. As my father related the story many years later as we drove to a local guitar studio, on the day of his lesson he'd leave his family home with guitar in hand but leave it at his friend's house to go play soccer with his buddies. One day, my grandfather saw the guitarist at the family owned taverna in the Friatitha neighborhood of town and inquired about his son's progress with guitar lessons. To say he was not happy to have paid a few months' lessons in advance is an understatement. When my parents provided me the opportunity to learn to play a musical instrument, I was given a choice-my uncle was a professional musician (alto saxophone, clarinet, flute, and bouzouki), and not knowing my father's story, I choose guitar. Three weeks later The Beatles appeared on Ed Sullivan and my fate was sealed. Every week, my "Baba" would drive me to the weekly lesson. He'd often sit nearby the studio door and listen to my lesson. He knew when I'd practiced and when I'd not played well. As the years progressed, my parents made many sacrifices to provided me with quality instruments-a ' 67 Gibson ES335 that I wish I'd kept, a '72 Guild F50R that I still play, and a '76 Paulo Bernabè classical guitar that I foolishly sold in 1990 when I became an assistant professor (thinking that I'd no longer need a classical guitar as a music education researcher). For my life in music, I owe it all to my parents and musician uncle, George Giordas, who provided an immediate role model of professionalism and musicality.

Like Margaret O'Sullivan shares in her story of practicing the piano, I always played for my father-either directly or indirectly, whether providing background music while he read the newspaper after work or practicing in the dining room while he watched television in the kitchen. Thus, when I first read O'Sullivan's inquiry three years ago ${ }^{19}$ it resonated so deeply with me that I cried. Good stories always inspire and beget more stories. That is inevitable because humans share experience directly or indirectly, knowingly or unknowingly. After many years of teaching ABER and CAP forms of research, I learned that to invite evocative 
writing I needed to provide provocative writing examples from the first week of the course, as well as fictional and non-fictional short stories that both tell and show how the writing should look, feel, and read. Contrary to traditional forms of research that aim to generalize the results and 'findings' to a broader population or a different sample, arts based research forms work from the 'outside-in'-a reader brings experiences to the reading of a story or poem makes connections with the author's ideas because the work resonates within them. Some readers may be disturbed that O'Sullivan's story stands alone, without theoretical grounding and nuanced discussion, but there are many examples of poems and stories in refereed research journals. The format of O'Sullivan's paper is not unlike many others. ${ }^{20}$

\section{Moving forward}

Parallel to the artistic notion conveyed by Pike (2004), the 'significance' of forms of Arts Based Research and Creative Analytical Practices is in their fundamentally ontological character in the ways that they enable researchers to raise issues of being and existence-not only to our own consciousness, but to others who read these works. Writing in a skillful and artful compositional style is more difficult than meets the eye, mind, and heart. Often, it's a matter of (re)learning how to write. To draw a parallel meaning from a quote concerning the art of teaching by Duane Huebner, a researcher must grapple with the "intricacies, absurdities, and dissonances" $(1962 / 1999,24)$ of experiences, without seeking to reduce them to neat data text boxes, formulas, graphs, charts, and text that is devoid of the writer's voice, feelings, deeply personal thoughts and convictions, and ideas once thought to be too personal and subjective for 'research.' It reminds me of how 25-30 years ago, music education researchers would never have conceived of socioemotional learning outcomes as a core consideration in research on teaching and learning music. Now we can't imagine our profession without that topic at the forefront of essential readings. Because of the subjectivities of most topics in that realm, it's difficult for me not to conceive most socioemotional topics written in ABER or CAP forms. A serious, deep dive into all the issues of Qualitative Inquiry will hopefully lead a reader to the notion that artful research methods that resist the objectification of emotion, feelings, and dare I say, aesthetic experiences are the most sensible ways to write about subjective topics that are at the core of, and intersect with, many aspects of music and musicking. I am certain that within a decade, music 
researchers will look at the present issue of $\mathrm{ACT}$ and reflect on the important directions and contributions that ABER and CAP afforded us.

Enough of my ideas and musings.

I would like to thank, with sincere gratitude, all the authors whose works are included in the present volume. They have put themselves 'out there' and I consider them innovators of our profession. I'd especially like to acknowledge Vincent Bates, without whose encouragement, vision, and invitation this special issue would never have come into existence. I'd also like to thank the MayDay founders for inviting me to present four ABER papers over the past 19 years. They weren't always heartily accepted, and many times they were either misunderstood or misinterpreted, but the presentations always evoked animated conversations. MayDay colloquia gave me (and my graduate students) the opportunity to present new ideas and receive useful feedback. And all four papers were eventually published in major, peer reviewed arts journals (Gouzouasis 2006; Gouzouasis, Henrey and Belliveau 2008; Prendergast, Gouzouasis, Leggo and Irwin 2009; Gouzouasis et al. 2014). For two of those publications, and another one (Gouzouasis and Ryu 2015), I must thank Sarah Hennessey, former editor of Music Education Research, for her insights, interest, and support in introducing innovative forms of research to our profession.

Lately I've been singing, "it's not easy being green," ${ }^{21}$ and as the forward thinking researchers who formed the MayDay Group and the ACT journal know, it has not been easy being at the forefront of innovation in music education. I offer a sincere thank you, MayDay Group, for supporting this scholarly endeavor.

breathe in, out again

hear the entire world from here

the heart's beat - music $^{22}$

\section{References}

Aoki, Ted T. 2005. Revisiting the notions of leadership and identity. In Curriculum in a new key: The collected works of Ted T. Aoki, edited by William F. Pinar and Rita L. Irwin, 349-55. Mahwah, NJ: Lawrence Erlbaum. (Original work published 1987). 
Bakan, Daniel L. 2014. A song of songs: A/r/togrpaphy, autoethnography, and songwriting as music education research. Unpublished doctoral dissertation, University of British Columbia, Vancouver, Canada. https://open.library.ubc.ca/cIRcle/collections/ubctheses/24/items/1.0167101

Banks, Stephen P., and Anna Banks. 2000. Reading "the critical life:" Autoethnography as pedagogy. Communication Education 49 (3): 233-8.

Barone, Thomas E., and Elliot W. Eisner. 1997. Arts based educational research. In Complimentary methods for research in education, edited by R. M. Jaeger, 73-103. Washington, DC: American Educational Research Association.

Barone, Thomas E. 1997. Ways of being at risk: The case of Billy Charles Barnett. In Complimentary methods for research in education, edited by R. M. Jaeger, 105-116. Washington, DC: American Educational Research Association.

Beer, Ruth S. 1999. Landscape and identity: Three artist/teachers in British Columbia. Unpublished doctoral dissertation, University of British Columbia, Vancouver, Canada. https://open.library.ubc.ca/cIRcle/collections/ubctheses/831/items/1.0089260

Bochner, Art P., and Carolyn Ellis. 1992. Personal narrative as a social approach to interpersonal communication. Communication Theory 2 (2): 165-72.

Bruner, Jerome. 1991. The narrative construction of reality. Critical Inquiry 18 (1): 1-21.

Carr, Margaret. 2001. Assessment in early childhood research: Learning stories. Thousand Oaks, CA: Sage Publications Inc.

Carr, Margaret, and Wendy Lee. 2012. Learning stories: Constructing learner identities in early education. Thousand Oaks, CA: Sage Publications Inc.

Couser, G. Thomas. 1997. Recovering bodies: Illness, disability, and life writing. Madison, WI: University of Wisconsin Press.

Darts, David. 2004. Visual culture jam: Art, pedagogy and creative resistance. Unpublished doctoral dissertation, University of British Columbia, Vancouver, Canada. https://open.library.ubc.ca/cIRcle/collections/ubctheses/831/items $/ 1.0055131$

de Cosson, Alex F. 2003. (Re)searching sculpted a/r/tography: (Re)learning subverted knowing through aporetic praxis. Dissertation, The University of British Columbia. https://open.library.ubc.ca/cIRcle/collections/ubctheses/831/ items/1.0091201 
Deo, Candice, and Peter Gouzouasis. 2018. To build a home. Qualitative Research in Psychology. https://doi.org/10.1080/14780887.2018.1442668

Denzin, Norman K., and Yvonna S. Lincoln, eds. 2000. The handbook of qualitative research (2nd ed.). Thousand Oaks, CA: Sage Publications.

Denzin, Norman K., and Yvonna S. Lincoln, eds. 2008. The landscape of qualitative research (3rd ed.). Thousand Oaks, CA: Sage Publications.

Dunbar, C. Jr. 1999. Three short stories. Qualitative Inquiry 5 (1): 130-40.

Dunlop, Rishma. 2006. Following the curve of a sentence: Notes from a reader's diary English teaching: Practice and critique 5 (3): 59-92.

Dunlop, Rishma. 1999. 'Boundary Bay': A novel as educational research. Unpublished doctoral dissertation, University of British Columbia, Vancouver, Canada. https://open.library.ubc.ca/collections/ubctheses/831/items/ 1.0078142

Eisner, Elliot W. 1995. What artistically crafted research can help us to understand about schools. Educational Theory 45 (1): 1-7.

Eisner Elliot W. 1971. How can you measure a rainbow? Tactics for evaluating the teaching of art. Art Education, 24 (5): 36-9.

Ellis, Carolyn. 2004. The Ethnographic I: A methodological novel about autoethnography. Ethnographic alternatives book series. Walnut Creek, CA: AltaMira Press.

Ellis, Carolyn, Toney E. Adams, and Arthur P. Bochner. 2011. Autoethnography: An overview. Historical Social Research / Historische Sozialforschung 36: 4 (138): 273-90.

Fels, Lynn. 1999. In the wind clothes dance on a line: Performative inquiry-a (re)search methodology: Possibilities and absences within a space moment of imagining a universe. Unpublished doctoral dissertation, University of British Columbia, Vancouver, Canada. https://open.library.ubc.ca/cIRcle/collections/ubctheses/831/items/1.0078144

Fulford, Robert. 1999. The triumph of narrative: Storytelling in the age of mass culture. New York, NY: Broadway.

Gouzouasis, Peter. 2018. A/r/tographic inquiry in a new tonality: The relationality of music and poetry. In Handbook of Arts Based Research, edited by Patricia Leavy, 233-46. New York: Guilford Press. 
Gouzouasis, Peter, and Matthew Yanko. 2018a. Learning stories and Reggio Emilia inspired documentation: Formative methods of assessment for the elementary school music classroom. In the Handbook of cultural studies and education, edited by Peter Pericles Trifonas and Susan Jagger, 486-582. New York: Routledge.

Gouzouasis, Peter, and Matthew Yanko. 2018b. Reggio's arpeggio: Becoming pedagogical through autoethnography. In Meaning making in early childhood research: Pedagogies and the personal, edited by Will Parnell and Jeanne Marie Iorio, 56-70. New York: Routledge.

Gouzouasis, Peter, and Carl Leggo. 2017. Performative research in music and poetry: A pedagogy of listening. In The Routledge International Handbook of Intercultural Arts Research, edited by Pamela Burnard, Elizabeth Mackinlay and Kimberly. Powell, 454-66. New York: Routledge.

Gouzouasis, Peter, and Chris Regier. 2015. Adolescent love and relationships: A songwriting teacher's autoethnography. Journal of Artistic \& Creative Education 9 (1): 68-98.

Gouzouasis, Peter, and Jee Yeon Ryu. 2015. A pedagogical tale from the piano studio: Autoethnography in early childhood music education research. Music Education Research 17 (4): 397-420.

Gouzouasis, Peter, Danny Bakan, Jee Yeon Ryu, Helen Ballam, David Murphy, Diana Ihnatovych, Zoltan Virag, and Matthew Yanko. 2014. Where do teachers and learners stand in music education research? A multi-voiced call for a new ethos of music education research. International Journal of Education \& the Arts 15 (15). Retrieved from http://www.ijea.org/v15n15/

Gouzouasis, Peter, Rita L. Irwin, Clare Gordon, and Emily Miles. 2013. Commitments to a community of artistic inquiry: Becoming pedagogical through $\mathrm{a} / \mathrm{r} /$ tography in teacher education. International Journal of Education \& the Arts 14 (1). Available at http://www.ijea.org/v14n1/v14n1.pdf

Gouzouasis, Peter. 2013. The metaphor of tonality in artography. The UNESCO Observatory E-Journal 3 (2). Available at http://web.education.unimelb .edu.au/UNESCO/ejournal/index.html

Gouzouasis, Peter. 2008. Toccata on assessment, validity, and interpretation. In Being with $a / r /$ tography, edited by Stephanie Springgay, Rita L. Irwin, Carl Leggo, and Peter Gouzouasis, 219-30. Rotterdam: SensePublishers. 
Gouzouasis, Peter, Julia Henrey, and George Belliveau. 2008. Turning points: A transitional story of grade seven students' participation in high school band programs. Music Education Research 10 (1): 75-90.

Gouzouasis, Peter. 2006. A/r/tography in music research: A reunification of musician, researcher, and teacher. The Arts and Learning Research Journal 22 (1): 23-42. https://www.academia.edu/2561940/A_r_tography_in_music_ research_A_reunification_of_musician_researcher_and_teacher

Gouzouasis, Peter. 1992. An organismic model of music learning for young children. Update: Applications of Research in Music Education 11 (1): 13-18.

Gouzouasis, Peter. 1991. A progressive developmental approach to the music education of preschool children. Canadian Music Educator 32 (3): 45-53. https://www.academia.edu/2587313/A_progressive_developmental_approach_to_the_music_education_of_preschool_children

Gouzouasis, Peter. 1985. Speech and music production skills of young children. Unpublished paper from a developmental psychology doctoral seminar (Psych 837) with Professor David Goldstein. doi:0.13140/RG.2.2.17634.84166

Huebner, Dwayne E. 1962/1999. The art of teaching. In The lure of the transcendent: Collected essays by Dwayne E. Huebner, edited by Vikki Hillis, collected and introduced by William F. Pinar, 23-35. Mahwah, NJ: Lawrence Erlbaum.

Irwin, Rita L., and Alex de Cosson, eds. 2004. A/r/tography: Rendering self through arts-based living inquiry. Vancouver, BC: Pacific Education Press.

Janesick, Valerie. 2001. Intuition and creativity: A pas de deux for qualitative researchers. Qualitative Inquiry 7 (5): 531-40.

Kilbourne, Brent. 1999. Fictional theses. Educational Researcher 28 (9): 27-32.

Kirkland, Kevin Harvey. 2004. A grim fairy tale: A mythopoetic discourse on taboo, trauma and anti-oppressive pedagogy. Unpublished doctoral dissertation, University of British Columbia, Vancouver, Canada. https://open. library.ubc.ca/cIRcle/collections/ubctheses/831/items/1.0091723

Lee, Karen Vickie 2004. Riffs of change: Musicians becoming music educators. Unpublished doctoral dissertation, University of British Columbia, Vancouver, Canada. https://open.library.ubc.ca/cIRcle/collections/ubctheses/831/items /1.0055047

Lee, Karen Vickie, and Peter Gouzouasis. 2008. Out of the cage. In The authentic dissertation: Alternative ways of knowing research and representation, edited by Don Four Arrows Jacobs, 149-55. London: RoutledgeFalmer. 
Lee, Karen Vickie, and Peter Gouzouasis. 2002. Do you hear what I hear? Musicians composing the truth. Teacher Education Quarterly 29 (4): 125-41.

Leggo, Carl. 1995. Storying the word/Storying the world. English Quarterly 28 (1): $5^{-11 .}$

Miller, Lorrie. 2002. Constructing voices: A narrative case study of the processes and production of a community art performance. Unpublished doctoral dissertation, University of British Columbia, Vancouver, Canada. https://open.library.ubc.ca/cIRcle/collections/ubctheses/831/items/1.0099669

Overton, Willis F. 2015. Processes, relations and relational-developmental-systems. In Theory and Method. Volume 1: The handbook of child psychology and developmental science, edited by W. F. Overton and P. C. M. Molenaar (7th ed), editor-in-chief: Richard M. Lerner, 9-62. Hoboken, NJ: Wiley.

Overton, Willis F. 2013. A new paradigm for developmental science: Relationism and relational-developmental systems. Applied Developmental Science 17 (2): 94-107.

Overton, Willis F. 2003. Development across the life span. In Handbook of psychology, edited by Irving B. Weiner (Volume 1), 11-42. New York, NY: Wiley.

Overton, Willis F. 1998. Developmental psychology: Philosophy, concepts, and methodology. In Handbook of child psychology, edited by W. Damon (Vol. 1. $5^{\text {th }}$ ed.), 107-188. New York: Wiley.

Palmer, Parker. 2007. The courage to teach: Exploring the inner landscape of a teacher's life. San Francisco, CA: John Wiley \& Sons, Inc.

Pelias, Ron. 2000. The critical life. Communication Education 49 (3): 220-28.

Phillips, Denis C. 1995. Art as research, research as art. Educational Theory 45 (1): $1-7$.

Pike, Mark A. 2004. Aesthetic teaching. Journal of Aesthetic Education 38 (2): $20-37$.

Pinar, William F. 1975. The method of "currere.” Paper presented at the Annual Meeting of the American Research Association, Washington, DC. https://files.eric.ed.gov/fulltext/ED104766.pdf

Pinar, William F. 1978. What is the Reconceptualization? Journal of Curriculum Theorizing 1 (1): 93-104. 
Prendergast, Monica, Peter Gouzouasis, Carl Leggo, and Rita Irwin. 2009. A Haiku suite: The importance of music making in the lives of secondary students. $M u-$ sic Education Research 11 (3): 303-317.

Prendergast, Monica, Julie Lymburner, Kit Grauer, Rita Irwin, Carl Leggo, and Peter Gouzouasis. 2008. Pedagogy of trace: Poetic representations of teaching resilience/resistance in arts education. Vitae Scholasticae: The Journal of Educational Biography 25, 58-76.

Rainbow, Edward L., and Hildegard C. Froelich. 1987. Research in music education: An introduction to systematic inquiry. New York: Schirmer Books.

Rasberry, Gary W. 1997. Imagining the curious time of researching pedagogy. Unpublished doctoral dissertation, University of British Columbia, Vancouver, Canada. https://open.library.ubc.ca/cIRcle/collections/ubctheses/831/items /1.0054997

Richardson, Laurel. 2013. Audience matters. Keynote address presented at the 9th International Congress of Qualitative Inquiry, University of Illinois UrbanaChampaign. Unpublished manuscript received from the author May 25, 2013.

Richardson, Laurel. 2000. Writing: A method of inquiry. In Handbook of qualitative research (2nd ed.), edited by Norman K. Denzin and Yvonna S. Lincoln, 923-48. Thousand Oaks, CA: Sage.

Richardson, Laurel. 1998. Meta-Jeopardy. Qualitative Inquiry 4 (4): 464-8.

Richardson, Laurel. 1990. Writing strategies: Researching diverse audiences. Newbury Park, CA: Sage Publications, Inc.

Schwandt, Thomas A. 1996. Farewell to criteriology. Qualitative Inquiry 2 (1): $58-$ 72.

Schön, Donald. 1987. Educating the reflective practitioner. San Francisco: Jossey Bass.

Sinner, Anita, Carl Leggo, Rita Irwin, Peter Gouzouasis, and Kit Grauer. 2006. Arts-based educational research dissertations: Reviewing the practices of new scholars. The Canadian Journal of Education 29 (4): 1223-70.

Sparkes, Andrew C. 2002. Autoethnography, self-indulgence or something more? In Ethnographically speaking: Autoethnography, literature and aesthetics, edited by Arthur Bochner and Carolyn Ellis, 209-232. New York: Alta Mira Press. 
Thompson, Joan. 2001. 'I feel therefore I am': Selected British and Canadian senior high school students' conceptions of music and music education. Unpublished doctoral dissertation, University of British Columbia, Vancouver, Canada.

Van Maanen, John, ed. 1995. Representation in ethnography. Thousand Oaks, CA: SAGE.

Van Maanen, John. 1988. Tales from the field: On writing ethnography. Chicago: University of Chicago Press.

Yanko, Matthew, and Peter Gouzouasis. (in press). The timbre of a rainbow: Storied forms of assessment and the aesthetic experiences of young learners. In The international handbook of theory and research in cultural studies and education, edited by Peter P. Trifonas. Netherlands: Springer.

\section{Notes}

${ }^{1}$ I continued through the first decade of the new millennium to hand search qualitative journals across many disciplines and still do so, always surprised when I find a paper that I somehow 'missed'.

${ }^{2}$ And the first textbook I used to teach graduate music education research classes promoted that perspective, which arguably was the landscape of the profession well into the 1990 s and new millennium (see Rainbow and Froelich 1987).

3 The observations eventually wound up, many years later, in Gouzouasis 1991; 1992. Those publications, and my thesis, were also informed by Gouzouasis 1985 .

4 The organicist world view has evolved into a relational stance-relative relativist, amodernist, foundational metatheory in developmental psychology where emotions, thinking, and perception are considered as actively changing mental organizations. Notably and in skillful detail, Willis Overton describes how precursors to the relational metatheoretical/methodological stance can be traced to the writings of Plato, Aristotle, Gottfried Leibniz, Immanuel Kant, and Georg Hegel, as well as in the pragmatics of Charles Pierce, William James, and John Dewey. Contemporary philosophers Hans Georg Gadamer and Charles Taylor have also contributed to significant features of the stance, as have historians and philosophers of science Richard Bernstein, Larry Laudan, and Bruno Latour. For more details, see Overton 2015, 2013, 2003, 1998 (NB: his grappling with these topics go back to the early 1970s; see https://sites.temple.edu/woverton/files/2018/o2/OvertonVita2018. pdf). 
5 I use the term 'trace' to describe a trail, track, or pathway. Also, see Prendergast et al. 2008.

${ }^{6}$ Over the past decade, I have drawn from the Greek language to extend the applications of the 'auto' (pronounced 'afto' in Greek).

${ }^{7} \mathrm{He}$ was as unaware of that work as I was of his paper, until I came across Kilbourne's paper a few years ago while disposing of old, hard copy issues of Educational Researcher. Dunlop, an award winning Canadian poet and (full) professor of creative writing at York University, presented a keynote address at one of the NIME conferences at ASU over a decade ago. Sadly, she passed away at a very young age in 2016.

8 My father was from Piraeus and survived both WW2 and the communist uprising that followed; he could beautifully sing and acrobatically dance rembetiko music.

Rembetiko is a counterculture tradition and musical style that emerged out of the fusion of Western and Ottoman music in Greece and Asia Minor in the late 1800 , and thrived in the cafés along the trade routes that connected Pireaus, Smyrna (now Izmir), Beirut, Alexandria, Constantinople (now Istanbul), Thessaloniki, Siros, and Cyprus. The music was associated with lower classes because the topical content was not unlike the blues-sex, drugs (hashish), drinking (ouzo, raki, and various grappa-like liquors), failed love and heartbreak, abuse, death, and various criminal and other disreputable activities. That led to a national ban on the music by the mid 1930s. It's important to note how rembetiko and blues evolved during the same time period, and that recordings were made in Chicago and New York City as early as the turn of the 20th century. (https://www.loc.gov/audio/?fa=subject\%3Arebetika\%7Clocation\%3Agreece\&all=true)

Some of the most important composers who took this music into a more popularized style-not unlike the transition from blues to early rock and roll in North America and then the UK-were Manos Hadzidakis (who received an Academy Award for Best Original Song in "Never on Sunday," also known as "The Boys of Pireaus"), Manos Vamvarakis, and Vassilis Tsitsanis. My father used to sing many of their songs all day long in his basement workshop-usually accompanied by old, scratchy $16 \mathrm{rpm}$ and $78 \mathrm{rpm}$ records.

'Manga' were considered as 'cool cats' or 'tough guys' who had a particular style of wearing their hats (i.e. severely tilted), and jackets (i.e. usually wearing one sleeve of a jacket), a particular way of walking, and other mannerisms (e.g. either playing guitar, bouzouki, or baglama with lit cigarettes between fingers of the right hand and the plectrum, or sticking them on the ends of strings on the headstock) that were very unusual (and offensive) to religious, more conservative Greeks. As a young man, my father bore a striking resemblance to swashbuckler actor, Errol Flynn. 
9 While there are practical applications of narrative inquiry that still make senseafter all the research purpose and questions lead a researcher to select an appropriate research method-since the landmark chapters of Barone and Eisner (1997) and Barone (1997) more artfully, creatively composed narratives (i.e. as 'stories' in the author's voice, without dialogue or performative text) became folded into Arts Based Educational Research to become one of many tools an ABER researcher uses. ${ }^{10}$ In Greek, 'pedi' ( $\left.\pi a \imath \delta i\right)$ refers to a child, 'enilikas,' an adult; 'enìlikos' (phonetic

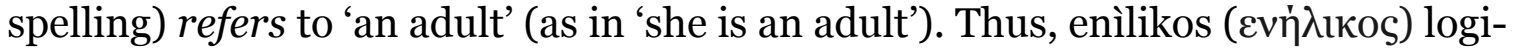
cally leads to coining the term enilikogogy (or 'enilikogy') as the adult equivalent of pedagogy. Please note that there are three letters that sound like 'ee' in Greek as well as a number of diphthongs that represent an 'ee' sound, so enilikos is pronounced 'eneeleekos' (accent on the first long 'ee' sound); even though I'm trying to accurately translate the sound of the words in Greek, my representation falls short using English characters (as it usually does, which leads to gross mispronunciations of most philosophical and scientific Greek terms used in English).

${ }^{11}$ One well-known conference attendee fell asleep in the audience, but I attributed that to time zone changes and travel and not boredom with the performative presentation.

${ }^{12}$ See https://plato.stanford.edu/entries/plato-myths/

${ }^{13}$ Not only does music evoke memories, feelings and novel ideas, it facilitates the nuanced recall of events-told through stories-that otherwise would not be possible without a musical 'anchor.' Moreover, an epiphony connects multiple stories in one's life that relate not only to the writer but to others who experienced the same, or a similar, event through a specific music performance or listening experience.

${ }^{14}$ See Gouzouasis and Regier (2014) for that interpretation and application of 'auto'.

${ }^{15}$ As a personal epiphony, it reminded me of the time I was invited to a bembè-a religious ceremony of the Yoruba peoples by Latin percussionists who in commercial settings also played salsa and jazz-in Philadelphia during the mid 1980s when I was music director of the most listened to $24 / 7$ jazz public radio station in the USA, WRTI/JAZZ9o.

${ }^{16}$ Not to detract from Hollingsworth's heartful story or her account of Ruth Crawford Seeger's relationship with her husband, but based on my own experiences (including two failed marriages) and those of other men who have struggled to make a life in music, I would suggest that an unsupportive, emotionally debilitating, mean spirited, abusive spouse is not a gender specific phenomenon. But that's another story. 
17 I use the terms story, tale, and narrative interchangeably and specifically refer to narrative inquiry when discussing that approach. See Robert Fulford (1999).

${ }^{18}$ See Gouzouasis and Ryu 2015.

${ }^{19}$ Ms. O'Sullivan took an autoethnography course with me in May 2017 and the prototype of this paper was first shared with graduate students, from various educational disciplines, in that class.

${ }^{20}$ As a very recent example, see Deo and Gouzouasis 2018.

${ }^{21}$ https://www.youtube.com/watch?v=hpiIWMWWVco

22 This haiku was written by Leggo and Gouzouasis, and ends the "Haiku Suite" paper by Prendergast et al. (2009) 